\title{
Variação nos parâmetros seminais em suínos destinados à inseminação artificial de acordo com a idade,época do ano, alojamento e coletador*
}

\author{
EDUARDO BALLESTER WOLLMANN \\ Fernando Pandolfo Bortolozzo (Orientador - UFRGS) \\ Ivo Wentz (Co-orientador-UFRGS)
}

Banca: Mari L. Bernardi (UFRGS), Rubens Stahlberg (UFMG), Rui F. F. Lopes (UFRGS)

O objetivo desta análise observacional foi estabelecer curvas de produção espermática de acordo com a idade dos animais (IDA) e com os meses do ano (MES). Paralelamente, estabelecer diferenças na produção espermática em função do tipo de alojamento (LOC) em que os animais estavam alocados (baias e gaiolas) e diferenças no número de espermatozóides de acordo com os coletadores (COL). Os dados foram coletados em uma central de inseminação artificial (CIA) com capacidade para 164 machos, de uma agroindústria localizada no meio-oeste catarinense, durante os meses de abril de 2000 a março de 2001. A unidade experimental considerada foi o macho, sendo cada coleta considerada uma repetição. Para a análise da IDA foram utilizados dados de todos os machos AgPIC 420 em coleta no período da observação ( $\mathrm{n}=118$ machos e 6.471 coletas). As idades foram categorizadas em períodos de dois meses objetivando a formação de uma curva detalhada. Para as análises do MES, COL e LOC, foram utilizados animais AgPIC 420 com idade entre 13 e 29 meses ( $n=53$ machos e 2.687 coletas analisadas). Os parâmetros analisados foram: volume seminal (VOL), concentração espermática (CONC), número total de espermatozóides por coleta (SPTZ TOT), motilidade (MOT) e morfologia espermática (MORF). O desempenho entre coletadores foi realizado avaliando três funcionários (A, B e C) que desempenharam esta função ao longo do período observacional. Foi observado um aumento no SPTZ TOT de acordo com a IDA dos 7 aos 19 meses, uma estabilização entre os 19 e 31 meses (X=87,15 x 10 espermatozóides/ coleta) com variação entre médias de $3,85 \%$, e queda de $8,7 \%$ até os 35 meses de idade ( $\mathrm{P}<0,05)$. O VOL foi crescente até 19 meses e decaiu a partir dos 25 meses. A CONC foi decrescente até os 23 meses e crescente até o $33^{\circ}$ mês $(\mathrm{P}<0,05)$. A MOT foi decrescente de acordo com a IDA $(\mathrm{P}<0,05)$, enquanto que não foram observadas diferenças na MORF de acordo com a IDA (P>0,05). Os maiores valores no SPTZ TOT de acordo com o MÊS, foram observados entre abril e junho e os menores entre agosto e dezembro ( $\mathrm{P}<0,05)$, com variação de $25,3 \%$ ao longo do ano. $\mathrm{O}$ VOL apresentou as maiores médias entre abril e julho, enquanto que as menores médias obtidas foram entre novembro e janeiro $(\mathrm{P}<0,05)$. A CONC foi inversamente proporcional ao VOL. A MOT foi mais alta nos meses em que foram observadas as maiores produções de SPTZ TOT, e não foram observadas diferenças na MORF. Machos alojados em baias produziram 5,2 x $10^{9}$ mais SPTZ TOT e $17,5 \mathrm{~mL}$ a mais de VOL que machos alojados em gaiolas $(\mathrm{P}<0,05)$. Não foram observadas diferenças biologicamente significativas para CONC, MOT e MORF. Foram observadas diferenças entre COL para SPTZ TOT, VOL e CONC $(\mathrm{P}<0,01)$. Não houve diferenças entre COL para MOT e MORF. Desta maneira, pode-se afirmar que, nas condições em que foram feitas as observações: a) há uma estabilidade no SPTZ TOT dos 19 aos 31 meses de idade; b) há variação de 25,3\% no SPTZTOT ao longo do ano; c) há a influência da mão-de-obra no SPTZ TOT; d) machos alojados em gaiolas produzem menos SPTZ TOT que machos alojados em baias.

Descritores: inseminação artificial, cachaço, produção espermática, idade, época do ano, coletador, alojamento.

Apresentada: 16 abril 2002

\footnotetext{
* Dissertação de Mestrado n. 330 (Especialidade: Fisiopatologia da Reprodução). 68f. Programa de Pós-Graduação em Ciências Veterinárias, Faculdade de Veterinária de Porto Alegre - UFRGS. CORRESPONDÊNCIA: E.B. Wollmann [e-mail: eduwoll@hotmail.com].
} 


\title{
Variation in semen parameters of boars used for artificial insemination according to age, time of the year, housing facilities and semen collector**
}

\author{
EDUARDO BALLESTER WOLLMANN
}

\author{
Fernando Pandolfo Bortolozzo (Adviser - UFRGS) \\ Ivo Wentz (Co-Adviser - UFRGS)
}

Committee: Mari L. Bernardi (UFRGS), Rubens Stahlberg (UFMG), Rui F. F. Lopes (UFRGS)

The goal of this observational analysis was to establish sperm production curves according to the animals' age (AGE) and months of the year (MONTH). At the same time, to establish differences in sperm production as a function of type of place (PLACE) where animals were located (pens and cages) and differences in sperm counts according to semen collectors (COL). Data were collected in an artificial insemination center (AIC) with capacity for 164 boars from a agribusiness located in the Mid-West of Santa Catarina State from April 2000 to March 2001. The experimental unit considered was the boar and each collection was considered as a repetition. For AGE analysis, data from all AgPIC 420 boars under semen collection in the observation period ( $\mathrm{n}=118$ boars and 6,471 semen collections) were used. Ages were classified by two-months periods in order to establish a detailed curve. For the analyses of MONTH, COL and PLACE, AgPIC 420 boars aged 13 to 29 months ( $\mathrm{n}=53$ boars and 2,687 semen collections) were used. The following parameters were analyzed: semen volume (VOL), sperm concentration (CONC), total sperm count per semen collection (TOT SPERM), motility (MOT) and sperm morphology (MORPH). Semen collections were performed by three employees (A, $\mathrm{B}$ and $\mathrm{C}$ ), who carried out this job during the observation period. An increase in TOT SPERM was found according to AGE from 7 to 19 months, with a stabilization between 19 and 31 months (X=87.15 x $10^{9} \mathrm{sperm} /$ collection) with a $3.85 \%$ variation among averages and a $8.7 \%$ decrease until 35 months of age $(\mathrm{P}<0.05)$. We found that VOL increased until 19 months and started to decrease starting at 25 months. CONC decreased until 23 months and increased until the 33rd month $(\mathrm{P}<0.005)$. MOT decreased according to AGE $(\mathrm{P}<0.05)$, while no differences in MORPH were found according to AGE (P>0.05). The greatest values in TOT SPERM according to MONTH were found between April and June and the lowest ones between August and December $(\mathrm{P}<0.05)$, with a $25.3 \%$ variation in the year (throughout the year). VOL had the highest averages between April and July, while the lowest averages were found between November and January $(\mathrm{P}<0.05)$. CONC was inversely proportional to VOL. MOT was highest in the months with the greatest TOT SPERM productions and no differences in MORPH were found. Boars in pens produced 5.2 x $10^{9}$ more TOT SPERM and $17.5 \mathrm{~mL}$ more VOL than boars in cages $(\mathrm{P}<0.05)$. No biologically significant differences were found in CONC, MOT and MORPH. Differences among COL were found in TOT SPERM, VOL and CONC $(\mathrm{P}<0.01)$, but not for MOT and MORPH. Thus, we can state that under the conditions where observations were carried out: a) there was a stability in TOT SPERM from 19 to 31 months of age; b) a 25.3\% variation in TOT SPERM throughout the year; c) there is an influence of labor in TOT SPERM; d) boars placed in cages produce less TOT SPERM than their counterparts placed in pens.

Key words: artificial insemination, boar, sperm production, age, time of the year, collector, placement.

Presented: 16 april 2002

\footnotetext{
**Master's Thesis no. 330 (Field: Theriogenology ). 68p. Postgraduate Program in Veterinary Sciences, Faculdade de Veterinária de Porto Alegre, Universidade Federal do Rio Grande do Sul (UFRGS) - Brazil. CORRESPONDENCE: E.B. Wollmann [e-mail: eduwoll@ hotmail.com].
} 